\title{
Bioadsorption of $\mathrm{Pb}^{2+}$ and $\mathrm{Cu}^{2+}$ on Eucalyptus
}

\section{Camaldulensis Leaves}

\author{
Zeinab Ezzeddine ${ }^{1}$, Effat Al Sayed ${ }^{2}$, Hassan Rammal ${ }^{1}$, Akram Hijazi ${ }^{1}$, Hussein \\ Hamad $^{* 1,3}$, Hanane Akhdar ${ }^{4}$
}

\author{
${ }^{1}$ Platform for research and analysis in environmental sciences (PRASE), Lebanese University, Beirut, Lebanon \\ ${ }^{2}$ Lebanese University, Faculty of Sciences (I), Hadath, Beirut, Lebanon \\ ${ }^{3,4}$ Lebanese University, Faculty of Sciences (V), Nabatieh, Lebanon
}

\begin{abstract}
Herein, the efficiency of Eucalyptus camaldulensis leaves as biosorbent for lead and copper was investigated. The particle size distribution was determined by Granulometric analysis and the functional groups were identified by FT-IR spectroscopy. The effects of contact time, $p H$ and initial metal ions concentration were investigated. The experimental kinetic data were well fitted by the pseudo-second order kinetic model and Langmuir isotherm with a maximum adsorption capacity up to $71 \mathrm{mg} \mathrm{g}^{-1}$ and $37 \mathrm{mg} \mathrm{g}^{-1}$ for $\mathrm{Cu}^{2+}$ and $\mathrm{Pb}^{2+}$ respectively. The selectivity was examined in a binary ions solution where the adsorbent showed preference for lead over copper.
\end{abstract}

Keywords- Biosorption, Eucalyptus leaves, copper, lead.

\section{INTRODUCTION}

Access to clean water is essential for the development of any country. Currently, many water resources are contaminated due to the direct discharge of domestic and industrial wastewater [1]. Contrary to organic pollutants, heavy metals are more dangerous since they are not biodegradable and thus persist in nature. The latter cause heavy metals transformation to the food chain through their accumulation by plants and animals which leads to several toxic health effects [2]. The ingestion of copper, zinc, cadmium, lead, mercury, iron and nickel in amounts exceeding guidelines damages severely human physiology [3]. Several treatment techniques for heavy metals removal from wastewater have been reported in literature [4]. Chemical precipitation, ion exchange and adsorption are among these methods are. For low metal ions concentrations in wastewater, adsorption is recommended for their removal. It is advisable that the adsorbent is available in large quantities, easily regenerable, and cheap [5]. Biosorption of heavy metals from aqueous solutions has proven very promising. Materials derived from low-cost agricultural wastes can be used for the effective removal and recovery of heavy metal ions [6]. The major advantages of biosorption over conventional treatment methods include: low-cost; high efficiency; minimization of chemical sludge; and the possibility of metal recovery [7]. The cost advantage of this technology would guarantee a strong penetration of the large market of heavy metal polluting industries. Several studies have shown that non-living plant biomass materials are effective for the removal of trace metals from the environment [8].

Eucalyptus tree is one of the most widely distributed trees in most of arid and semiarid areas. This kind of tree exists in Lebanon. Accordingly, the objective of this study is to investigate the adsorption potential of Eucalyptus leaves for the removal of $\mathrm{Cu}^{2+}$ and $\mathrm{Pb}^{2+}$ from wastewater within various experimental conditions.

\section{MATERIALS AND METHODS}

\subsection{Adsorbent preparation}

Eucalyptus camaldulensis leaves were collected from Bekaa-Lebanon. The leaves were thoroughly rinsed with water to remove impurities like soluble materials and dust then dried in the oven at $50{ }^{\circ} \mathrm{C}$ for 48 hours. The dried Eucalyptus leaves were then grinded to fine powder.

2.2. Characterization of the Eucalyptus leaves

The granulometric analysis was done to the grinded leaves in order to determine size distribution before and after modification using Partica LA-950V2 Horiba. The functional groups were identified by Fourier Transform Infrared (FTIR) Spectroscopy in the range of 4000-400 $\mathrm{cm}-1$. The samples were first mixed with $\mathrm{KBr}$ and then pressed into pellets and analyzed with FT-IR -6300 JASCO.

2.3. Batch adsorption tests

Lead and copper solutions were prepared from the corresponding nitrate salts in distilled water to obtain solutions of different concentrations. The $\mathrm{pH}$ of the solution was adjusted using $0.1 \mathrm{M} \mathrm{HNO}_{3}$ and $0.1 \mathrm{M} \mathrm{NaOH}$ solution. In typical batch studies, $0.5 \mathrm{~g}$ of eucalyptus leaves powder was placed in a flask containing $50 \mathrm{~mL}$ of a metal solution with the desired concentration. The flask was continuously stirred at room temperature $\left(25 \pm 2^{\circ} \mathrm{C}\right)$, 
except where the effect of temperature was being investigated, at $250 \mathrm{rpm}$ for $180 \mathrm{~min}$. At the end of each step the solution was filtered and the metal ion concentration was determined for each metal using Atomic Adsorption Spectrophotometer (RAYLEIGH WFX-210) equipped with Automatic hollow cathode lamp changeover and air-acetylene burner. The equilibrium time was determined as the contact time required for the metals in the solution to reach equilibrium. The lead adsorption percentage was calculated by equation (1):

$$
R=\frac{\mathrm{C}_{0}-\mathrm{C}_{\mathrm{t}}}{\mathrm{C}_{0}} \times 100
$$

where $\mathrm{R}$ is the adsorption rate $(\%), \mathrm{C}_{0}$ is the initial concentration and $\mathrm{C}_{\mathrm{t}}$ is the concentration at time $\mathrm{t}$. The adsorption capacity of the adsorbent at equilibrium was calculated by equation (2):

$$
q_{e}=\frac{\left(\mathrm{C}_{0}-\mathrm{C}_{\mathrm{e}}\right) \mathrm{V}}{\mathrm{m}}
$$

Where qe is the equilibrium adsorption capacity in $\mathrm{mg} \mathrm{g}^{-1}$, $\mathrm{C}_{0}$ is the initial concentration and $\mathrm{C}_{\mathrm{e}}$ is the concentration at equilibrium, $\mathrm{V}$ is the volume in $\mathrm{L}$ of metal solution and $\mathrm{m}$ is the mass in $\mathrm{g}$ of the adsorbent. For obtaining the isotherms, the batch experiments the initial metal ions concentrations were varied between $50 \mathrm{mg} \mathrm{L}^{-1}$ and 500 $\mathrm{mg} \mathrm{L}^{-1}$. The solutions were then filtered by a $0.45 \mu \mathrm{m}$ nylon syringe filter and the remaining metal ions were measured by AAS in order to calculate $\mathrm{Ce}$ and qe.

\section{RESULTS AND DISCUSSION}

\subsection{Granulometric analysis}

Fig. 1.a shows the size distribution of the grinded powder of Eucalyptus leaves. The obtained results showed two particle distribution populations with average diameter 14.5 and $115 \mu \mathrm{m}$.

\subsection{FT-IR spectroscopy}

The obtained spectra for Eucalyptus leaves are shown in Fig. 1.b. The peak between $3400-3200 \mathrm{~cm}^{-1}$ is due to $\mathrm{OH}$ stretch. At $2925 \mathrm{~cm}^{-1}$, the peak could be assigned to $\mathrm{C}-\mathrm{H}$ stretching vibration. The absorption peak at $1750 \mathrm{~cm}^{-1}$ is characteristic to $-\mathrm{COOH}$ group and that at $1647 \mathrm{~cm}^{-1}$ can be attributed to $\mathrm{HN}_{2}$ bending vibration. The $\mathrm{C}-\mathrm{N}$ stretching vibration is at $1318 \mathrm{~cm}^{-1}$, while $\mathrm{C}-\mathrm{O}$ stretch is at $1032 \mathrm{~cm}^{-1}$. The peak at $886 \mathrm{~cm}-1$ and $646 \mathrm{~cm}^{-1}$ may be caused by $\mathrm{C}-\mathrm{H}-\mathrm{CH}_{2}$ bending. The peak at $500-473 \mathrm{~cm}^{-1}$ is attributed to polysulfide ( $\mathrm{S}-\mathrm{S}$ stretch).

3.3. Effect of $\mathrm{pH}$ on $\mathrm{Pb}^{2+}$ and $\mathrm{Cu}^{2+}$ adsorption

Fig. 2 shows the adsorption capacity of Eucalyptus leaves as a function of $\mathrm{pH}$. The obtained adsorption capacities were high over the studied $\mathrm{pH}$ range (between 2 and 8);
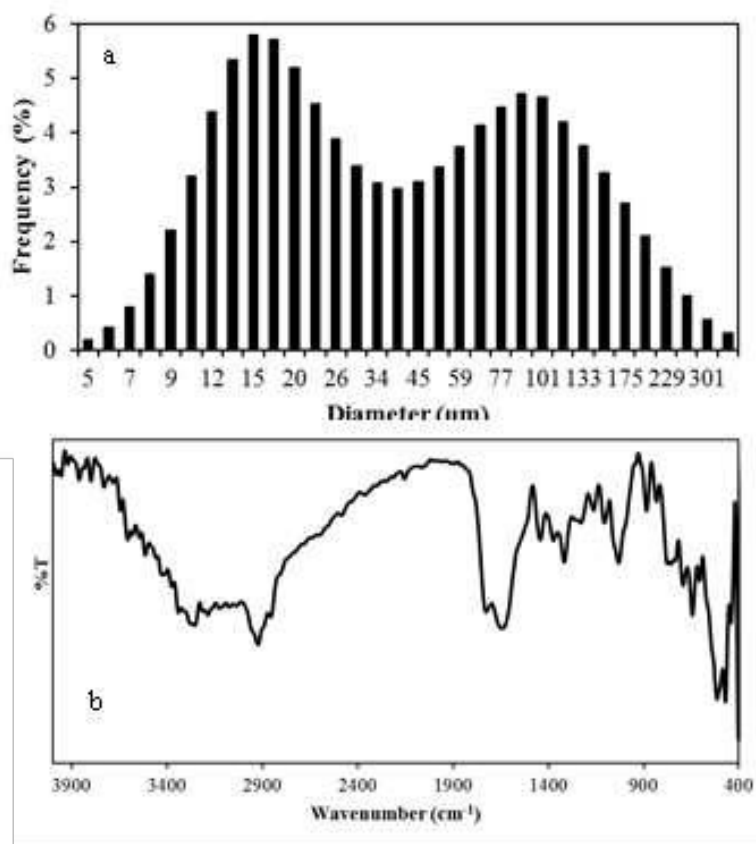

Fig. 1: Particle size distribution (a) and FT-IR spectrum (b) of Eucalyptus leaves.

However, the maximum adsorption capacity for $\mathrm{Pb}^{2+}$ was at $\mathrm{pH}=4$ and at 6 for $\mathrm{Cu}^{2+}$.

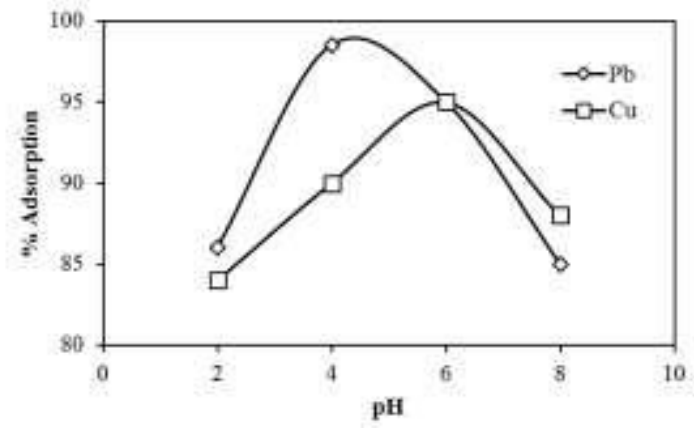

Fig. 2: Effect of $p H$ on metal ions biosorption $((m) /(V)=$ 0.5/50 $\mathrm{mg} \mathrm{mL}^{-1}$, at $25^{\circ} \mathrm{C}, 300 \mathrm{rpm}$ and $\left.\left[\mathrm{M}^{2+}\right]=50 \mathrm{ppm}\right)$.

\subsection{Adsorption Kinetic models}

3.4.1. Pseudo-first order

The pseudo first-order kinetic model is expressed as follows:

$$
\ln \left(q_{\mathrm{e}}-q_{\mathrm{t}}\right)=\ln q_{\mathrm{e}}-k_{\mathrm{l}} \mathrm{t}
$$

Where $q_{t}$ and $q_{e}$ are the quantity of metal ions adsorbed $\left(\mathrm{mg} \mathrm{g}^{-1}\right)$ at time $\mathrm{t}(\mathrm{min})$ and at equilibrium respectively, and $k_{1}$ is the rate constant of adsorption $\left(\mathrm{min}^{-1}\right)$. The plot of $\ln \left(q_{\mathrm{e}}-q_{\mathrm{t}}\right)$ versus $\mathrm{t}$ should give a linear relationship from which $k_{1}$ and $q_{\mathrm{e}}$ can be determined from the slope and intercept of the plot, respectively [9].

3.4.2. Pseudo-second order

The pseudo-second-order sorption rate is expressed as:

$$
\frac{\mathrm{t}}{\mathrm{q}_{\mathrm{t}}}=\frac{1}{k_{2} q_{e}^{2}}+\frac{t}{q_{e}}
$$

where $k_{2}$ is the pseudo-second order rate constant $\left(\mathrm{g} \mathrm{mg}^{-1}\right.$ $\left.\min ^{-1}\right), q_{\mathrm{t}}$ and $q_{\mathrm{e}}$ are the quantity of metal ions adsorbed at 
$\mathrm{t}$ time and at equilibrium $\left(\mathrm{mg} \mathrm{g}^{-1}\right)$ respectively. A plot of $\mathrm{t} / q_{\mathrm{t}}$ versus $\mathrm{t}$ should yield a straight line from which $q_{e}$ and $k_{2}$ can be determined from the slope and intercept of the plot, respectively [10].

Lead and copper adsorption as a function of contact time is illustrated in Fig. 3.a. Equilibrium was reached within the first 30 min for both metal ions which indicates the high affinity of the adsorbents towards them. The kinetic parameters as well as the correlation coefficients $\left(\mathrm{R}^{2}\right)$ and the experimental equilibrium capacities are reported in Table 1. The obtained results show that $\mathrm{Pb}^{2+}$ and $\mathrm{Cu}^{2+}$ adsorption on Eucalyptus leaves followed the pseudosecond order kinetic model (Fig. 3.b). This suggests that the adsorption rate depends mainly on the interaction between different functional groups present on the leaves and the metal ions.

Table.2: Comparison of Langmuir and Freundlich models for $\mathrm{Me}^{2+}$ adsorption on Eucalyptus leaves

\begin{tabular}{|c|c|c|c|c|c|c|}
\hline \multirow[b]{2}{*}{$\mathrm{Me}^{2+}$} & \multicolumn{3}{|c|}{$\begin{array}{c}\text { Langmuir } \\
\text { model }\end{array}$} & \multicolumn{3}{|c|}{ Freundlich model } \\
\hline & $q^{\exp } a_{\max }$ & $\mathrm{K}_{\mathrm{L}}$ & $\mathrm{R}^{2}$ & $n$ & $\overline{K_{f}}$ & $\mathrm{R}^{2}$ \\
\hline $\mathrm{Cu}^{2+}$ & 71 & 0.02 & 0.875 & 1.46 & 2.15 & 0.996 \\
\hline $\mathrm{Pb}^{2+}$ & 37 & 0.06 & 0.988 & 2.3 & 4.5 & 0.983 \\
\hline
\end{tabular}
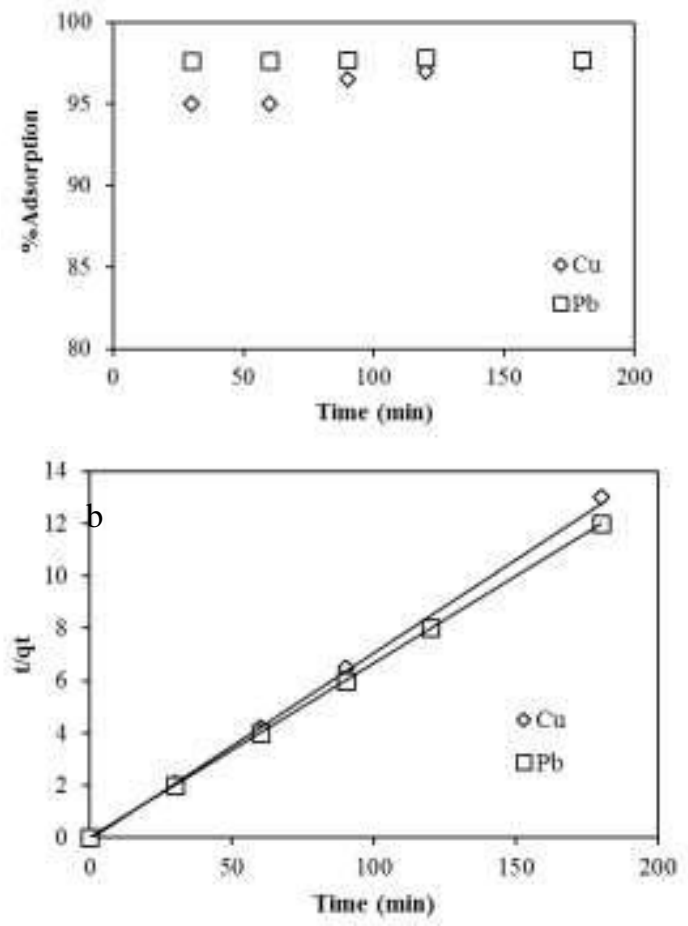

Fig.3: biosorption of $M^{2+}$ as a function of time (a) and pseudo-second-order model $(b)\left((\mathrm{m}) /(\mathrm{V})=0.5 / 50 \mathrm{mg} \mathrm{mL}^{-}\right.$ ${ }^{1}$, at $25^{\circ} \mathrm{C}, 300 \mathrm{rpm}$ and $\left.\left[\mathrm{M}^{2+}\right]=50 \mathrm{ppm}\right)$
Table.1: Comparison of the first and the second order kinetic models Eucalyptus leaves

\begin{tabular}{lc|ccc|cccc}
\hline & \multicolumn{3}{|c|}{$\begin{array}{c}\text { First order kinetic } \\
\text { model }\end{array}$} & \multicolumn{3}{c}{$\begin{array}{c}\text { Second order kinetic } \\
\text { model }\end{array}$} \\
\cline { 3 - 8 } & $\mathrm{qe}^{\text {exp }}$ & $k_{1}$ & $\mathrm{qe}^{\text {cal }}$ & $\mathrm{R}^{2}$ & $k_{2}$ & $\mathrm{qe}^{\text {cal }}$ & $\mathrm{R}^{2}$ \\
\hline $\mathrm{Cu}^{2+}$ & 14.3 & 0.023 & 13 & 0.949 & 0.087 & 14.7 & 0.999 \\
$\mathrm{~Pb}^{2+}$ & 15 & 0.009 & 15.6 & 0.948 & 0.514 & 14.7 & 0.999 \\
\hline
\end{tabular}

Langmuir Isotherm is a model that assumes monolayer coverage of a finite number of identical sites present on the surface such that no further adsorption takes place.

Based on these assumptions, Langmuir represented the following equation [11]:

$$
q_{e}=\frac{\mathrm{K}_{\mathrm{L}} \times q_{\max } C_{e}}{1+\mathrm{K}_{\mathrm{L}} C_{e}}
$$

where $q_{\max }$ is the maximum adsorption capacity (monolayer coverage), i.e. mmol of the adsorbate per ( $\mathrm{g}$ ) of adsorbent and $\mathrm{K}_{\mathrm{L}}$ is Langmuir isotherm constant. The adsorption parameters of Langmuir model can be determined from its linear form by sketching $C_{e} / q_{e}$ versus $C_{e}$ so that the values of $q_{\max }$ and $\mathrm{K}_{\mathrm{L}}$ can be calculated from the slope and intercept of the linear plot respectively:

\section{Freundlich Isotherm:}

$$
\frac{C_{e}}{q_{e}}=\frac{1}{\mathrm{~K}_{\mathrm{L}} q_{\max }}+\frac{\mathrm{C}_{\mathrm{e}}}{q_{\max }}
$$

This model describes the non-ideal and reversible adsorption, not limited to monolayer formation. It can be applied to multilayer adsorption, with non-uniform distribution of adsorption heat and affinities over a heterogeneous surface [12]. The equation is expressed as follows:

$$
q_{e}=K_{f} C_{e}^{1 / n}
$$

Where $K_{f}$ is Freundlich isotherm constant $\left(\mathrm{mmol} \mathrm{g}^{-1}\right)$ and $\mathrm{n}$ is the adsorption intensity. The linear form:

$$
\log q_{e}=\log K_{f}+\frac{1}{\mathrm{n}} \log C_{e}
$$

The theoretical fittings for the experimental data are shown in Fig. 4 and the calculated parameters are shown in Table 2. The linear regression correlation coefficients $\mathrm{R}^{2}$ show that the equilibrium data could be well interpreted by the Langmuir isotherm with maximum adsorption capacity $q_{\max }$ equals to $71 \mathrm{mg} \mathrm{g}^{-1}$ and $37 \mathrm{mg} \mathrm{g}^{-1}$ for $\mathrm{Cu}^{2+}$ and $\mathrm{Pb}^{2+}$ respectively.

\subsection{Adsorption Isotherms}

Langmuir Isotherm: 


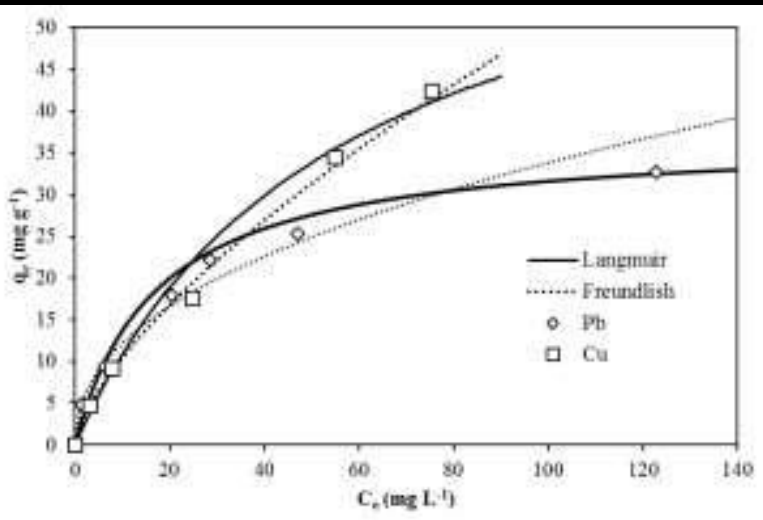

Fig. 4: Langmuir and Freundlish fit for the experimental



$$
\left.\left[\mathrm{M}^{2+}\right]=50-500 \mathrm{ppm}\right)
$$

3.6 Selectivity for $\mathrm{Pb}^{2+} / \mathrm{Cu}^{2+}$ in binary ions solution The competition in binary solutes was obtained by testing the adsorption capacity of the adsorbent in a mixed solution containing both lead and copper ions (both at 50 ppm). Figure 5 shows the adsorption percentages of these two metals. Eucalyptus leaves showed preference for lead over copper and this could be explained by the smaller size of hydrated lead ions.

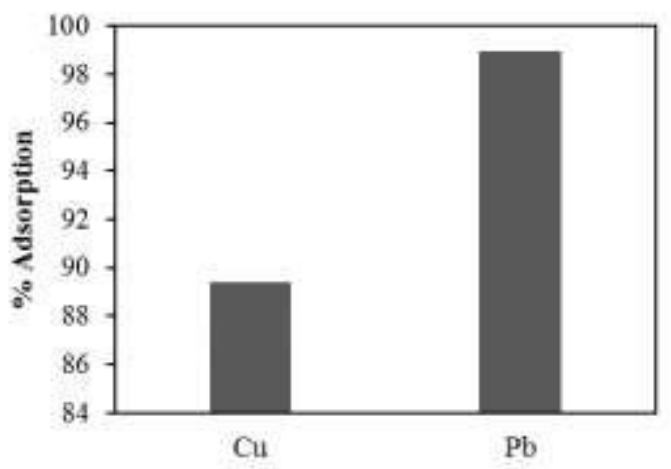

Fig. 5: Selectivity of Eucalyptus leaves in a binary metal ions solution $\left((\mathrm{m}) /(\mathrm{V})=0.5 / 50 \mathrm{mg} \mathrm{mL}^{-1}\right.$, at $25^{\circ} \mathrm{C}, 300$ rpm and $\left.\left[\mathrm{M}^{2+}\right]=50-500 \mathrm{ppm}\right)$.

\section{CONCLUSION}

In this study, the biosorption of lead and copper on Eucalyptus leaves was studied. The adsorption capacity was high at different $\mathrm{pH}$ values. The adsorption process followed the pseudo second order kinetic model. The maximum adsorption capacity was determined from Langmuir isotherm. The adsorbent was selective for lead in a binary metal solution containing both lead and copper.

\section{ACKNOWLEDGEMENTS}

The authors are thankful to Lebanese University for the financial support of this work.

\section{REFERENCES}

[1] Hussein Hamad, Zeinab Ezzeddine , Fatima Lakis , Hassan Rammal, Mortada Srour,Akram Hijazi. An insight into the removal of $\mathrm{Cu}$ (II) and $\mathrm{Pb}$ (II) by aminopropylmodified mesoporous carbon CMK-3: Adsorption capacity andmechanism. Materials Chemistry and Physics 178 (2016) 57-64.

[2] H. Hamad, Z. Ezzeddine, S. Kanaan, F. Lakis, A. Hijazi, M.A. Moussawi. A novel modification and selective route for the adsorption of $\mathrm{Pb} 2+$ by oak charcoal functionalized with glutaraldehyde. Advanced Powder Technology 27 (2016) 631-637.

[3] T. Bahadira, G. Bakana, L. Altasb, H. Buyukgungor, The investigation of lead removal by biosorption: an application at storage battery industry wastewaters, Enzyme Microb. Technol. 41 (2007) 98-102.

[4] P. Sin Keng, S. Ling Lee, S. Tiong Ha, Y. Tse Hung, S. Teng Ong, Removal of hazardous heavy metals from aqueous environment by low-cost adsorption materials, Environ. Chem. Lett. 12 (2014) 15-25.

[5] M.A. Hashem, Adsorption of lead ions from aqueous solution by okra wastes, Int. J. Phys. Sci. 2 (2007) 178-184.

[6] D. W.O'Connell, C. Birkinshaw, T. F. O’Dwyer. Heavy metal adsorbents prepared from the modification of cellulose: A review. Bioresource Technology 99 (2008) 6709-6724.

[7] A.Demirbas. Heavy metal adsorption onto agrobased waste materials: A review. Journal of Hazardous Materials 157 (2008) 220-229.

[8] L.Agwaramgbo, N. Lathan, S. Edwards, S. Nunez. Assessing Lead Removal from Contaminated Water Using Solid Biomaterials: Charcoal, Coffee, Tea, Fishbone, and Caffeine. Journal of Environmental Protection, 2013, 4, 741-745.

[9] Z. Ezzeddine, I. Batonneau-Gener, Y. Pouilloux, H. Hamad, Z. Saad, V. Kazpard, Divalent Heavy Metals Adsorption onto Different Types of EDTAModified Mesoporous Materials: Effectiveness and Complexation Rate, Microporous and Mesoporous Materials, 212 (2015) 125-136.

[10] K. Vasanth Kumar, Linear and non-linear regression analysis for the sorption kinetics of methylene blue onto activated carbon, J. Hazard. Mater. B137 (2006) 1538-1544.

[11]I. Langmuir, The constitution and fundamental properties of solids and liquids, J. Am. Chem. Soc. 38 (1916) 2221-2295.

[12] H.M. Freundlich, Uber die adsorption in $10^{\circ}$ sungen, J. Phy.Chem., 57 (1906) 385-471. 